\title{
PERANCANGAN SISTEM INFORMASI DANA DESA DI KABUPATEN KUDUS
}

\author{
Pratomo Setiaji \\ Fakultas Teknik, Program Studi Sistem Informasi \\ Universitas Muria Kudus \\ Email: pratomo.setiaji@umk.ac.id \\ Arif Setiawan \\ Fakultas Teknik, Program Studi Sistem Informasi \\ Universitas Muria Kudus \\ Email: arif.setiawan@umk.ac.id
}

\begin{abstract}
ABSTRAK
Kudus merupakan Kabupaten terkecil di Jawa Tengah dengan luas wilayah mencapai 2.516 Ha yang terbagi dalam 9 Kecamatan, desa yang ada di Kabupaten Kudus berjumlah 123 dimana pada tahun ini mendapatkan alokasi dana desa sebesar Rp 1,4 miliar, alokasi dana desa tidak akan dibagi rata. Alokasi dana untuk setiap desa disesuaikan dengan sejumlah kriteria seperti jumlah penduduk, tingkat kesejahteraan, serta sejumlah kriteria lainnya. Permasalahan yang timbul adalah mekanisme perencanaan dan penggunaan yang belum terdata dengan baik Permasalah tersebut dapat diatasi dengan penyajian informasi yang baik dan transparan, untuk itu diperlukan sebuah Sistem informasi dana desa untuk pengelolaan dana desa menggunakan metode waterfall. sistem informasi ini sangat berguna untuk memonitor dana desa dan serapan yang dilaksanakan tiap desa secara real time, juga sebagai informasi bagi kepala desa maupun pemangku kebijakan di Kabupaten Kudus untuk menetapkan sebuah kebijakan Penelitian ini menghasilkan sebuah model perancangan sistem yang berikan model waterfall dalam bentuk diagram use case, struktur penyimpanan data dan desain tampilan aplikasi.
\end{abstract}

Kata kunci: Sistem Informasi, dana desa.

\begin{abstract}
Semarang is the smallest district in Central Java with a total area of 2,516 hectares and is divided into nine districts, villages in Kudus regency which totaled 123 this year allocated funds amounting to Rp 1.4 billion in the village, the village fund allocation will not be shared equally. Allocation of funds for each village adapted to a number of criteria such as population, level of welfare, as well as a number of other criteria. Problems that arise are planning mechanisms and the use that has not been recorded properly Problems can be solved with a good presentation of information and transparency, it is necessary for an information system for the management of funds of funds rural village using waterfall method. This information system is very useful to monitor the village fund and uptake held every village in real time, as well as information for the village head and stakeholders in Kudus to establish a policy The study produced a model of the system design that give the waterfall model in the form of diagram use case, the data storage structure and design of the application.
\end{abstract}

Keywords: Information Systems, the village fund.

\section{PENDAHULUAN}

Kementerian Desa, Pembangunan Daerah Tertinggal (PDT) dan Transmigrasi akan menyalurkan dana desa sejumlah Rp 1,4 miliar untuk setiap desa. Pemberian dana ini dilakukan secara bertahap hingga lima tahun ke depan, Untuk tahun 2015 yang di luncurkan ada kurang lebih $\mathrm{Rp} 9,2$ triliun. (http://www.kemendagri.go.id/news/2014/11/11/dana-desa-rp-14-m-dikucurkan-bertahap-mulai-tahun2015)

Kabupaten Kudus merupakan salah satu kabupaten yang menerima dana desa tersebut, dengan kondisi geografis terletak pada persimpangan jalur transportasi utama Jakarta-Semarang-Surabaya dan Jepara-Grobogan, Kabupaten Kudus merupakan wilayah yang sangat strategis dan cepat berkembang serta memiliki peran utama sebagai pusat aktivitas ekonomi yang melayani wilayah kabupaten di sekitarnya. Kudus merupakan Kabupaten terkecil di Jawa Tengah dengan luas wilayah mencapai 2.516 
Ha yang terbagi dalam 9 Kecamatan, desa yang ada di Kabupaten Kudus berjumlah 123 dimana pada tahun ini mendapatkan alokasi dana desa sebesar Rp 1,4 miliar, menurut Kepala Bagian Pemerintahan Desa Kabupaten Kudus Adi Sadhono mengatakan, alokasi dana desa tidak akan dibagi rata. Alokasi dana untuk setiap desa disesuaikan dengan sejumlah kriteria seperti jumlah penduduk, tingkat kesejahteraan, serta sejumlah kriteria lainnya.

Penelitian yang menyajikan platform e-pemerintah yang mendukung akses publik yang mudah ke informasi pemerintah, e-transaksi antara warga dan organisasi masyarakat melalui penerimaan e-dokumen [1].

E-commerce dapat dimanfaatkan oleh berbagai pihak untuk meningkatkan proses bisnis seperti perusahaan, Model B2B mengintegrasikan antara perusahaan, mitra, pemasok dan distributor. Metode yang digunakan dalam penelitian ini adalah metode pengembangan sistem CEPAT (Kerangka Penerapan Teknik Sistem) dengan pendekatan prototyping. [2].

Tiga sasaran utama dari upaya penerapan SI atau TI dalam suatu organisasi. Pertama, memperbaiki efisiensi kerja dengan melakukan otomasi berbagai proses yang mengelola informasi. Kedua, meningkatkan keefektifan manajemen dengan memuaskan kebutuhan informasi guna pengambilan keputusan. Ketiga, memperbaiki daya saing atau meningkatkan keunggulan kompetitif organisasi dengan merubah gaya dan cara berbisnis [3].

Dalam jurnal ini akan dipublikasikan hasil penelitian yang telah dilakukan mengenai analisa dan perancangan sistem informasi dana desa di kabupaten Kudus dengan metode waterfall. sebagai upaya membantu pemerintah daerah dalam rangka pengelolaan dana sehingga informasi dana desa bisa diinformasikan secara baik.

\section{METODOLOGI}

Sejalan dengan tujuan yang ingin dicapai dalam penelitian ini, yakni analisa dan perancangan sistem informasi dana desa di kabupaten Kudus dengan metode waterfall, maka penelitian ini dilakukan dengan menggunakan kajian (research) terhadap model-model pengembangan yang sudah dilaksanakan dan kemudian berdasarkan hasil kajian itu merumuskan satu analisis dan desain analisa perancangan sistem informasi dana desa, kemudian dari model desain sistem ini dikembangkan menjadi model Aplikasi sistem informasi. Tahapan proses penelitian yang dilakukan ditunjukkan pada gambar 1 .

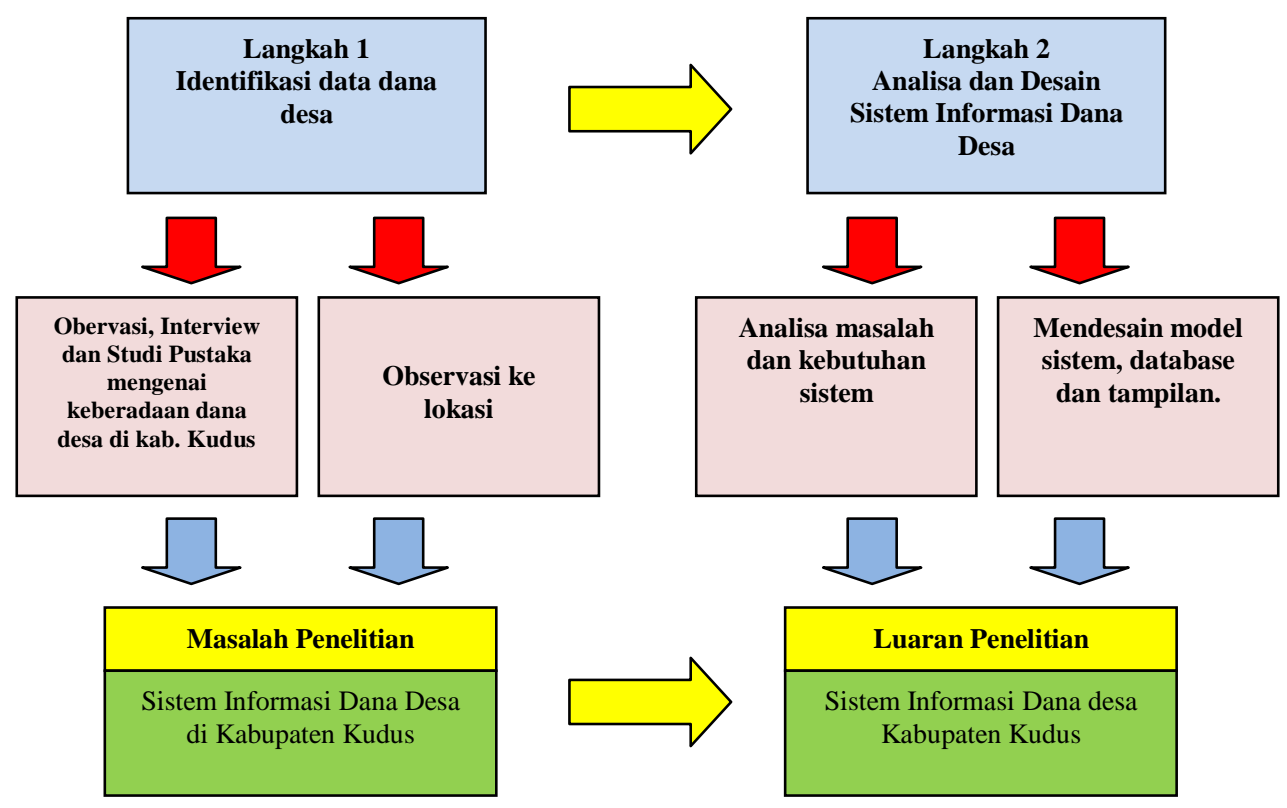

\section{Gambar 1. Tahapan proses penelitian}

Lokasi penelitian dilakukan di Kabupaten Kudus, dengan sumber data Desa diKabupaten Kudus, dan tempat penelitian di Laboratorium Rekayasa perangkat Lunak, Program Studi Sistem Informasi Fakultas Teknik Universitas Muria Kudus.

Variabel yang digunakan dalam proses perancangan analisa ini adalah jumlah format anggaran pendapatan dan anggaran pengelolaan yang akan di alokasikan sebagai pembelanjaan dan pembangunan desa di kabupaten Kudus. 
Desain model yang digunakan dalam membangun sistem informasi Dana desa di Kabupaten Kudus ini adalah menggunakan perancangan OOD (Object Oriented Desain) dan tool yang digunakan adalah Unified Modelling Language (UML). OOD adalah metode yang membawa kita ke dekomposisi berorientasi objek. Dengan menerapkan desain berorientasi objek, kita dapat menciptakan perangkat lunak yang tangguh dengan meminimalisasi penulisan ekspresi serta mengurangi risiko yang melekat dalam pengembangan sistem perangkat lunak yang kompleks [4]. Desain model yang termasuk di dalam UML adalah use case diagram, class diagram, sequence diagram, activity diagram, state diagram, collaboration diagram.

Teknik pengumpulan dan analisis data dalam penelitian ini adalah menggunakan observasi, studi pustaka, dan interview. Observasi dilakukan ke lokasi desa di Kabupaten Kudus, interview dilakukan dengan sumber data yaitu pihak perangkat desa di Kabupaten Kudus serta sampel penelitian dan studi pustaka dilakukan dengan mencari literatur dan jurnal mengenai Sistem Informasi.

Teknik analisa data dilakukan dengan tiga tahapan, yaitu : (1) mengidentifikasi dan menganalisa masalah sistem yang berjalan (problem analysis), dalam hal ini dilakukan analisa mengenai kendalakendala dalam proses penerimaan dan pengelolaan dana desa yang sudah digunakan selama ini, (2) mengidentifikasi dan menganalisa kriteria dan performance sistem yang dibutuhkan (requirements analysis), dalam hal ini dilakukan analisa mengenai kriteria sistem dana desa yang dibutuhkan, (3) memberikan alternatif sistem yang diusulkan (generating systems alternatif). Pada bagian ini dilakukan pemilihan sistem beserta input, proses dan output dari sistem informasi dana desa yang disesuaikan dengan kebutuhan.

\section{HASIL DAN PEMBAHASAN}

Sesuai dengan metodologi penelitian yang telah diteetapkan, berikut adalah hasil penelitian yang telah dicapai.

\subsection{Analisa Sistem}

Konsep sistem informasi dana desa telah dilaksanakan dengan menggunakan satu parameter, yaitu jumlah penerimaan dan pengelolaan dana desa. Proses penggunaan sistem informasi tidak dilaksanakan secara terjadwal, hanya jika ada penerimaan dan pengelolaan dana yang telah di berikan oleh pemerintah, maka penggunaan sistem informasi tersebut akan di masukkan dalam database dan hanya ditulis pada buku.

Dalam prakteknya penggunaan sistem informasi masih perlu banyak perbaikan dan pengembangan lebih lanjut, perbaikan yang masih perlu adalah merubah yang berbasis manual menjadi berbasis sistem terkomputerisasi sehingga tidak hanya pengguna sistem saja yang bisa melihat dan menggunakan sistem informasi ini tetapi para pemangku kebijakan dan masyarakat pada umumnya bisa melihat dan memantau apakah pengelolaan dan penerimaan dana itu sudah sesuai dengan kebutuhan masyarakat

Perbaikan dan pengembangan lebih lanjut tentunya akan sangat bermaanfaat jika dilakukan penelitian lanjutan sehingga data akan lebih akurat dan akan bisa memberikan informasi kepada dinas maupun kepada pemerintah sehingga proses informasi tersebut bisa ditampilkan secara cepat dan tepat sehingga tidak butuh waktu lama dalam pengolahan data menjadi sebuah informasi

\subsection{Analisa Kebutuhan}

Setelah melihat analisa masalah di atas, maka kriteria dan sistem baru yang dibutuhkan adalah sistem yang dapat membantu Desa di Kabupaten Kudus dalam melakukan proses pengelolaan dana desa, dengan kemampuan sistem sebagai berikut (1) Sistem aplikasi dapat memproses memasukkan anggaran dana yang diperoleh dari pemerintah secara tepat, (2) Sistem aplikasi juga dapat menghasilkan laporan dana yang relevan, (3) Laporan hasil pengelolaan dana bisa ditampilkan secara cepat dan tepat, sehingga bisa diketahui penerimaan dan pengelolaan untuk kemajuan desa. Untuk menganalisa kriteria dan sistem yang dibutuhkan, langkah yang dilakukan adalah sebagai berikut.

\subsubsection{Identifikasi Data}

Data penerimaan oleh desa yang mendapat bantuan dari pemerintah industri yang digunakan untuk pengembangan desa Atribut-atribut data yang diidentifikasi meliputi (1) jumlah dana desa yang diterima, (2) rencana penegembangan desa menggunakan dana desa dan (3) implementasi pengelolaan dana desa yang dibuat untuk pengembagan desa. 


\subsubsection{Analisa Informasi}

Informasi yang dibutuhkan pengguna sistem adalah informasi dana desa. Pengguna sistem adalah para staf desa di kabupaten Kudus dan pemangku kebijakan di Kabupaten Kudus.

\subsection{Desain Sistem}

Hasil dari analisa yang telah dilakukan kemudian dituangkan ke dalam model sistem dalam bentuk diagram pengguna, rincian struktur penyimpanan data dan layout tampilan aplikasi yang akan dihasilkan.

\subsubsection{Diagram Use Case}

Use case adalah spesifikasi dari kumpulan aksi yang dijalankan oleh sistem. Diagram use case untuk sistem informasi dana desa di tunjukkan pada gambar 2.

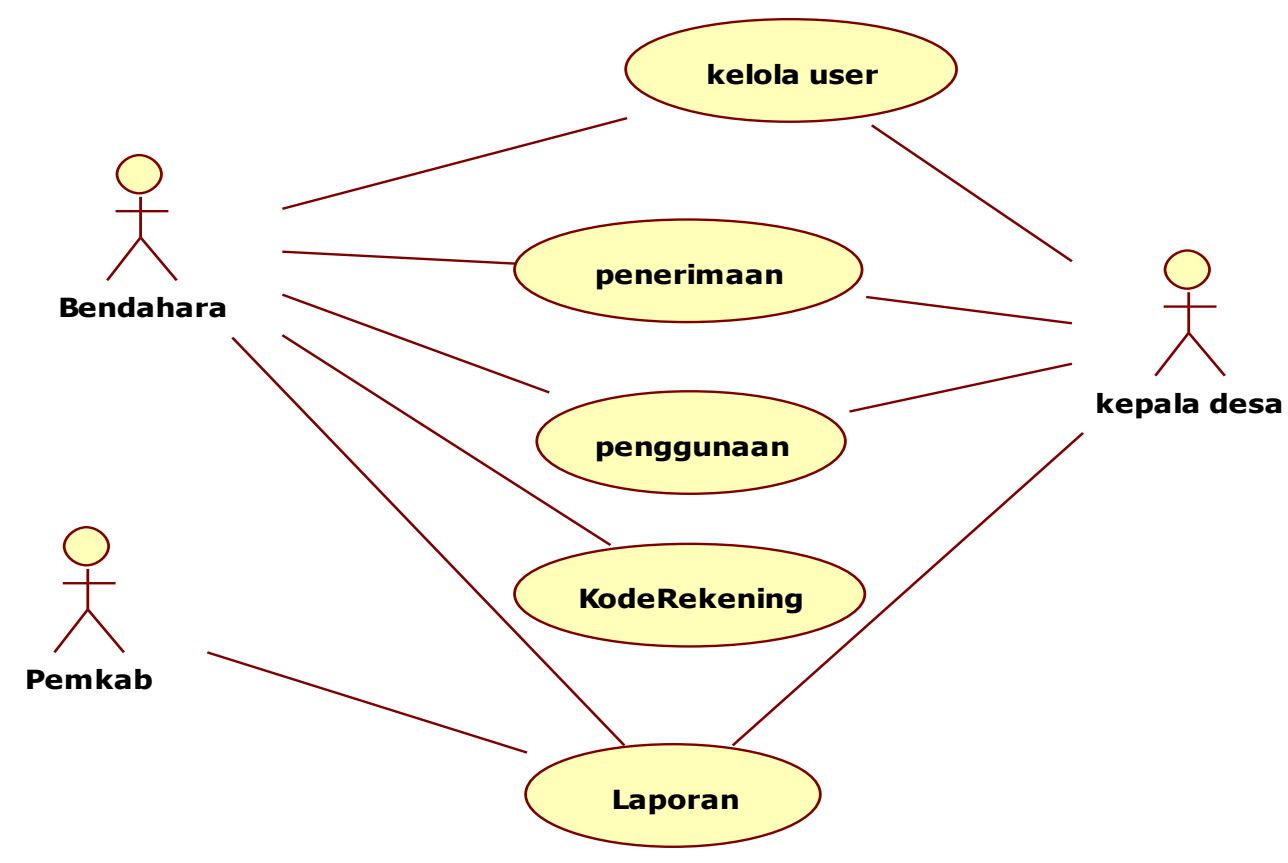

Gambar 2. Diagram use case sistem informasi dana desa

\subsubsection{Struktur Tabel Penyimpanan Data}

Aplikasi database yang digunakan untuk mengembangkan aplikasi adalah database server MySQL yang bersifat opensource. Terdapat sebuah database yang dirancang dalam aplikasi dana desa yaitu dbdanadesa. Database dbdanadesa memiliki 3 tabel yaitu tb_Rekening, tb_anggaran dan tb_user. Hubungan antar tabel dan strukturnya ditunjukkan pada gambar 3 .

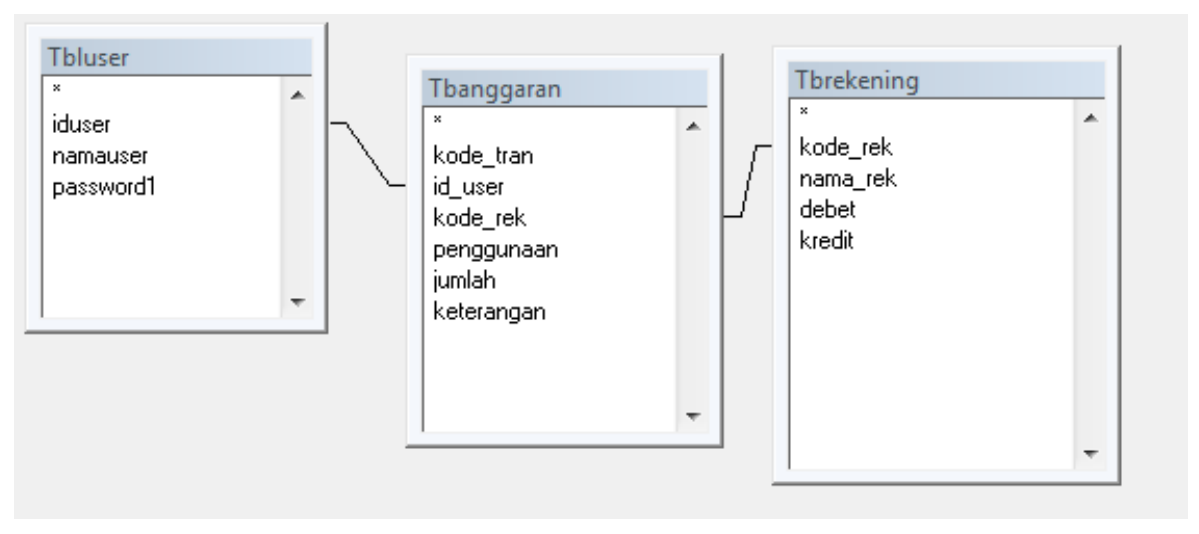

Gambar 3. Struktur dan hubungan antar tabel 


\subsubsection{Diagram Layout}

Aplikasi ini dibangun dengan menggunakan aplikasi visual foxpro untuk mengimplementasikan konsep dana desa. Desain tampilan akan disesuaikan dengan aplikasi yang akan digunakan. Pada gambar 4 ditunjukkan salah satu tampilan layout login dan gambar 5 dari menu utama aplikasi.

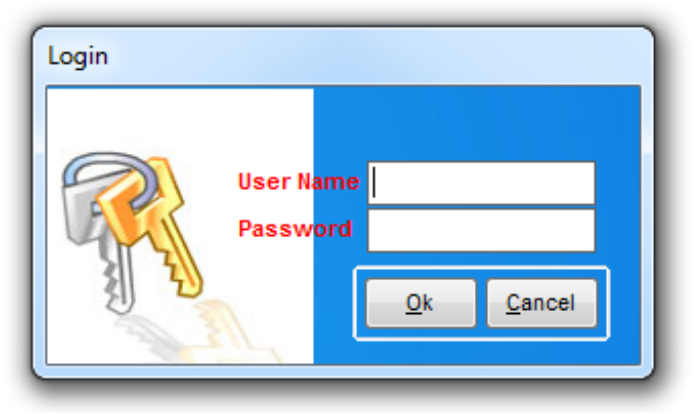

Gambar 4. Tampilan layout login

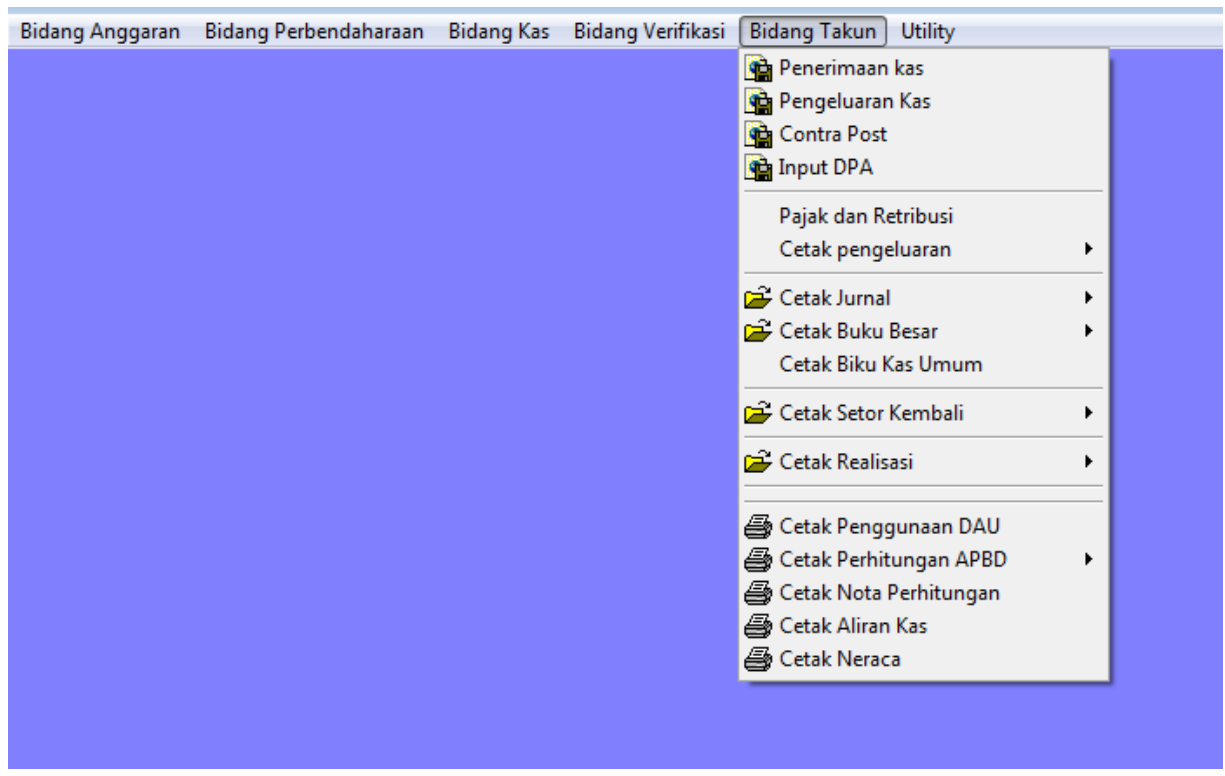

Gambar 5. Tampilan layout menu utama sistem informasi dana desa

\section{KESIMPULAN}

Dari penelitian yang sudah dilakukan dapat diambil kesimpulan bahwa :

a. Analisa perancangan sistem informasi dana desa melalui diagram use case yang dihasilkan menyediakan fasilitas untuk menggunakan aplikasi dalam penerimaan dan dana desa.

b. Amalisa perancangan sistem informasi dana desa memberikan alternatif bagi pengguna untuk bisa menyelesaikan pekerjaannya menggunakan sistem terkomputerisasi.

c. Pemetaan produk berpoten HKI berbasis GIS ini menggunakan 3 tabel yaitu tbanggaran, tbrekening dan tb_user.

\section{DAFTAR PUSTAKA}

[1] Athanasios S. Drigas and Lefteris Koukianakis E- Government Applications for the Information Society IJCSI International Journal of Computer Science Issues, Vol. 10, Issue 1, No 2, January 2013

[2] Maidoni F, Ruskan E L, Putra A Penerapan Model B2B Pada Sistem Informasi Berbasis Web (Studi Kasus Pt Semen Baturaja Persero) JSI Vol 2, No 1 (2010)

[3] Ward, John. and Joe Peppard. Strategic Planning for Information System 3nd ed. England: John Wiley \& Sons, 2002 
[4] Booch, Grady,. Maksimchuk, Robert A., Engle, Michael W., Young, Bobbi J., Conallen, Jim,. Houston, Kelli A., (2007), Object-Oriented Analysis and Design with Applications. Pearson Education, Inc, USA. Chapter 5, 147 - 154 